\title{
Roughness and stability of compound resin color exposed to bleaching strips after surface treatment
}

\author{
Rugosidade e estabilidade de cor após \\ clareamento caseiro
}

\author{
Izabelle Fiamma Alves Pessoa Matias CALIXTO' ${ }^{1}$ iD 0000-0001-6662-472X \\ Michelly Rodrigues Dantas GAMA ${ }^{1}$ iD 0000-0002-2248-7441 \\ Júlia Peixoto CAMPOS ${ }^{1}$ iD 0000-0003-3189-1806

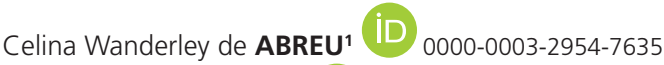 \\ Lucas Lactim FERRAREZ² iD 0000-0003-2717-8020 \\ Milene de OLIVEIRA ${ }^{3}$ iD 0000-0003-2096-7502
}

\section{ABSTRACT}

Objective: to analyze the surface roughness and color stability of the composite resin after surface treatment with the aluminum oxide discs and subsequent exposure to the Advanced Teeth Whitening Strips. Methods: 20 specimens of the Filtek Z350XT restorer (3M ${ }^{\circledR}$ ) were prepared and daily subjected to home bleaching for 30 minutes during 14 days. A precision rugosimeter was used in order to verify the roughness by means of 3 random readings in the same direction in each sample. For color stability the CIELAB system ( $L^{*}$, $a^{*}$, $b^{*}$ values) was used through the spectrophotometer (MINOLTA CR -321, Japan). The means of the test specimens as well as the mean of each group were calculated using the random readings. Data statistical analysis were performed by ANOVA- analysis of variance. The level of significance was set at $5 \%$ ( $p \leq 0.05)$. Results: Roughness did not present great numerical variations. No statistically significant difference between the means obtained concerning the surface roughness of the composite resin with $p=0.44$ was observed. However, it was found that there was a statistically significant difference between the means obtained in relation to the color stability of the composite resin, $p=0.007$. Conclusion: It was concluded that pre-contoured strips containing $6 \%$ hydrogen peroxide do not have a significant adverse effect on the roughness of Z350XT $\left(3 \mathrm{M}^{\circledR}\right)$ resin. However, it was also concluded that according to the color stability analysis performed, there may be an indication of the restoration replacement after the bleaching treatment, due to their color change.

Indexing terms: Composite resins. Tooth bleaching. Dental polishing.

\section{RESUMO}

Objetivo: Analisar a rugosidade superficial e a estabilidade da cor da resina composta após tratamento de superfície com os discos de óxido de alumínio e posterior exposição à fita clareadora Advanced Teeth Whitening Strips. Métodos: Foram confeccionados 20 corpos

$\boldsymbol{\nabla} \boldsymbol{\nabla} \boldsymbol{\nabla}$

${ }^{1}$ Centro Universitário CESMAC. Rua Cônego Machado 918, Farol, 57051-160, Maceió, AL. Brasil. Correspondência para /Correspondence to: IFAPM CALIXTO. E-mail: <belinha_fiamma@hotmail.com>.

2 Universidade Federal de Juiz de Fora, Faculdade de Odontologia, Programa de Pós Graduação em Odontologia. Juiz de Fora, MG, Brasil.

${ }^{3}$ Universidade Federal de Juiz de Fora, Faculdade de Odontologia, Departamento de Odontologia Restauradora. Juiz de Fora, MG, Brasil.

$\boldsymbol{\nabla} \mathbf{v}$

How to cite this article

Calixto IFPM, Gama MR, Campos JP, Ferrarez LL, Oliveira M.. Roughness and stability of compound resin color exposed to bleaching strips after surface treatment. RGO, Rev Gaúch Odontol. 2020;68:e20200005. http://dx.doi.org/10.1590/1981-86372020000053601 
de prova do restaurador universal Filtek Z350XT (3M $\left.{ }^{\circledR}\right)$, estes, foram submetidos ao clareamento caseiro por 30 minutos diários durante 14 dias. Utilizou-se um rugosímetro de precisão para verificação da rugosidade através de 3 leituras aleatórias no mesmo sentido em cada amostra, e para estabilidade de cor foi utilizado o sistema CIELAB (valores $L^{*}, a^{*}, b^{*}$ ), através do espectofotômetro (MINOLTA CR-321, Japão). As leituras coletadas possibilitaram o cálculo das médias dos corpos de prova e a média de cada grupo. Em seguida, os dados foram submetidos a tratamento estatístico pela análise de variância ANOVA. O nível de significância estabelecido foi de 5\% $(p \leq 0,05)$. Resultados: a rugosidade não sofreu grandes variações numéricas e também não houve diferença estatisticamente significantes entre as médias obtidas em relação a rugosidade superficial da resina composta $(p=0,44)$. Contudo, verificou-se que houve diferenças estatisticamente significantes entre as medias obtidas em relação à estabilidade de cor da resina composta, com $p=0,007$. Conclusão: As fitas pré-contornadas contendo peróxido de hidrogênio a $6 \%$ não provocam efeito adverso significantes sobre a rugosidade da resina Z350XT (3M $\left.{ }^{\circledR}\right)$. Contudo, também concluímos que, de acordo com a análise de estabilidade de cor realizada, poderá haver indicação da substituição das restaurações após o tratamento clareador devido à alteração na coloração das mesmas.

Termos de indexação: Resinas compostas. Clareamento dental. Polimento dentário.

\section{INTRODUCTION}

Since the introduction of home bleaching by Haywood and Heymann in 1989, this trend has become quite popular and aesthetics in Dentistry has been increasingly more noticeable [1]. Bleaching is a conservative, simple treatment, and usually used by professionals to achieve an aesthetically pleasant smile [2].Types of bleaching methods include in-office bleaching performed by the dentist, at home performed by the patient under the supervision of the professional; and also, the association of these techniques, part performed in the office and part at home [3].Bleaching occurs by oxidation reaction caused by the decomposition of hydrogen peroxide into oxygen and perhydroxyl, the carbamide peroxide breaks down into hydrogen peroxide and urea which again breaks down into ammonia and carbon dioxide. Free radicals are formed which split into large pigmented, then smaller chains and are totally or partially eliminated [2].

Disposable pre-contoured strips containing the hydrogen peroxide bleaching agent in concentrations ranging from 6 to $14 \%$ was introduced in Brazil, in 2013. These have been widely used due to the lower concentration of the bleaching agent, shorter application time and simple use [4]. According to the National Agency of Sanitary Surveillance (Anvisa), dental bleaching products should be sold only with the dentis'st prescription. Products withhigher than $3 \%$, concentrations of carbamide peroxide and hydrogen peroxide, which includes whitening strips [5] are under Anvisa assignment.Composite resins-very popular among dentists- have significantly been developed and widely used in restorative treatments. Thus, it is common in daily practice to find patients who present anterior teeth restorations in composite resins in order have some bleaching treatment performed $[6,7]$.It is known that the long-term clinical success of restorative procedures depends on several factors, including surface roughness and color stability [8]. There is a positive correlation between surface roughness and bacterial adhesion, since bleaching agents seem to affect the cariogenic microorganism adhesion on resin restoration surfaces. The roughness impairs aesthetics; causes restorationstaining; plate accumulation; caries and gingival irritation [1].

Color stability is an increasingly necessary feature, during the bleaching treatment and the restorative material can bear and even respond to the procedure [9]. New studies concerningthese materials effects are needed and patients should be warned about the replacement of existing restoration after bleaching [10]. In this context, the use of surface treatment procedures (finishing and polishing) has been indicated to improve the aesthetics and longevity of composite resin restorations [11]. However, further studies are essential in order to elucidate the question of whether these finishing and polishing treatments determine less significant alteration of the surface roughness and greater color stability for the resin composites during the bleaching procedures. Various finishing and polishing techniques can be used in composite resins however, some studies advocate the use of the complete sequence of aluminum oxide discs to obtain a better surface smoothness for composite resins [11].

Some studies have demonstrated that substances remaining from bleaching agents may negatively affect the clinical longevity of composite resin restorations [12], while other researches demonstrate that the changes in structure and longevity [13] are not meaningful. This shows lack of consensus on the effects of bleaching agents on composite resins, especially concerning bleaching strips. Although there is a strong indication of their damage further studies and research on the subject are required. Considering the several effects of bleaching agents on the surface of 
aesthetic restorative materials, mainly composite resins, this study aims to analyze the surface roughness and color stability of the composite resin after surface treatment with the aluminum oxide discs and subsequent exposure to the bleaching strips.

\section{METHODS}

The surface roughness and color stability of the Filtek Z350XT universal restorer (3M ESPE ${ }^{\circledR}$ ) in A2E color (Lot: 450491) was evaluated and stored at room temperature below $27^{\circ} \mathrm{C}$, according to the manufacturer's recommendation and which is a photopolymerizable composite resin developed for use in restorations of posterior and anterior teeth including occlusal surfaces after surface treatment (polishing) with aluminum oxide discs (Sof-Lex-3M ESPE ${ }^{\circledR}$ - lot: 01220813) in the 4 granulations (Thick, medium, fine and superfine) and after exposure to the Advanced Teeth Whitening Strips, which composition includes $6 \%$ of hydrogen peroxide as a bleaching agent, through the preparation of 20 specimens. The specimens were prepared by means of individualized metal matrices, each one having the shape of a cylinder with a central hole, $4 \mathrm{~mm}$ in height and $1 \mathrm{~cm}$ in diameter. The specimens were obtained by inserting the composite resin in increments of $2 \mathrm{~mm}$ each, with anti-adherent titanium spatula (Millenium ${ }^{\circledR}$ ), in the matrix central hole, followed by constant photoactivation for 20 seconds (Optilight Digital - Gnatus According to the manufacturer's instructions. A anti-adherent polyester strip $\left(\right.$ Fava $\left.^{\circledR}\right)$ was placed on a glass plate (Prisma ${ }^{\circledR}$ ) and then the matrix on the polyester strip for insertion of the composite resin. Another polyester strip was placed on the resin, and thus, the photopolymerization was performed. After the preparation, the specimens were placed in plastic containers containing $2 \mathrm{ml}$ of distilled water to simulate the oral medium and divided into 2 groups with 10 samples each (G1A and G1B, which after bleaching were called respectively $G 2 A$ and $G 2 B$ ), which are represented in the table 1:

Table 1. Distribution of experimental groups.

\begin{tabular}{lll}
\hline Groups & Surface treatment & \multicolumn{1}{c}{ Bleaching } \\
\hline$G_{1} A($ control $)$ & Polyester matrix & Bleaching strips $\left(G_{2} A\right)$ \\
\hline$G_{1} B$ & $G_{1} A+$ sof-Lex discs & Bleaching strips $\left(G_{2} B\right)$ \\
\hline
\end{tabular}

After identification, the specimens were stored at $37^{\circ}$ in a oven and $100 \%$ relative humidity for a period of 24 hours to certify complete polymerization and hydration. After the 24 hour storage, the G1B test specimens were subjected to surface treatment with the aluminum oxide discs (Sof-Lex 3M ${ }^{\circledast}$ ) in the 4 low-speed, and analysis of the surface roughness and color stability was performed, prior to the bleaching treatment, together with the G1A test specimens. Following the analys,Advanced Teeth Whitening Strips were applied for 30 minutes daily during 14 days, following the manufacturer's instructions. At each daily application, the specimens were washed with distilled water and stored again in the plastic containers with $2 \mathrm{ml}$ of distilled water. After exposure to the bleaching agent, all specimens were subjected to a new verification of surface roughness and color stabilityA $0.25 \mathrm{~mm}$ Roughness Specimen (NRB 3405 - jan / 88), whose Ra values were expressed in micrometers $(\mu \mathrm{m})$ for rugosimetric reading, was used to verify the roughness ( $\mathrm{Ra})$. Three random readings were taken in the same direction for each test specimen, not touching regions previously scratched in the reading. The color stability was analyzed by the CIELAB system ( ${ }^{*},{ }^{*}{ }^{*}, b$ * values) through the spectrophotometer (MINOLTA CR-321, Japan). Data were collected and readings allowed the calculation of the roughness means and color stability and the mean of each group. Finally, the means for the roughness and color stability of each specimen were submitted to statistical to ANOVA and significance was set at $5 \%$.

The supervisors of the present study are linked to Instituição Centro Universitário - CESMAC (Maceió-AL, Brazil). There was no submission to the ethics committee of this institution once the research was not performed on animals or humans.

\section{RESULTS}

Regarding surface roughness, the values obtained were tabulated containing the means and standard deviation of all groups (Table 2). Based on the values of the means it was observed that the roughness did not suffer great numerical variations. ANOVA (Table 3) was used to identify whether there were statistically significant differences between the surface treatment (polyester strip and soft lex disc finishing) before and after bleaching. It was verified that there was no statistically significant difference between the means obtained in relation to the surface roughness of the composite resin with $p=0.44$. 
Table 2. Surface roughness for composite resin befroe and after bleaching strips exposure

\begin{tabular}{lccc}
\hline Groups & Sample size & Mean \\
\hline $\mathrm{G}_{1} \mathrm{~A}$ & 10 & 0.13 & 0.08 \\
$\mathrm{G}_{2} \mathrm{~A}$ & 10 & 0.18 & 0.12 \\
$\mathrm{G}_{1} \mathrm{~B}$ & 10 & 0.13 & 0.16 \\
$\mathrm{G}_{2} \mathrm{~B}$ & 10 & 0.04 & 0.84 \\
\hline
\end{tabular}

Source: research data

Table 3. Factors for surfasse roughness.

\begin{tabular}{lccccc}
\hline Variation & SS & Df & MS & $F^{*}$ & Crit. F $^{*}$ \\
\hline Amongs groups & 0.02129 & 3 & 0.0071 & 0.90205 & 0.44967 \\
In the groups & 0.28322 & 36 & 0.00787 & \\
\hline Total & 0.30451 & 39 & & \\
\hline
\end{tabular}

Note: ${ }^{*} a \leq 0,05$

Table 4. Color stability of composite resin, before and after bleaching strips exposure.

\begin{tabular}{|c|c|c|c|}
\hline Groups & Sample size & Mean & Standard Deviation \\
\hline $\mathrm{G}_{1} \mathrm{~A}$ & 10 & 65.01 & 0.80 \\
\hline $\mathrm{G}_{2} \mathrm{~A}$ & 10 & 65.33 & 0.47 \\
\hline$G_{1} B$ & 10 & 64.30 & 0.68 \\
\hline $\mathrm{G}_{2} \mathrm{~B}$ & 10 & 65.09 & 0.54 \\
\hline
\end{tabular}

Table 5. Factors for color stability.

\begin{tabular}{lccccc}
\hline Origin of variation & SS & $d f$ & MS & Crit. F & F-level* \\
\hline Among groups & 5.83386 & 3 & 1.94462 & 4.72416 \\
In the groups & 14.81878 & 36 & 0.41163 & \\
\hline Total & 20.65264 & 39 & & \\
\hline
\end{tabular}

Note: * $a \leq 0,05$

Source: research data.

The means and standard deviation obtained in the color stability analysis are described in table 4 . According to ANOVA (table 5), a statistically significant difference was found between the means obtained in relation to the color stability of the composite resin, with $p=0.007$.

\section{DISCUSSION}

There is a strong relationship between bacterial adhesion and surface roughness, an important feature of dental material [14]. The $0.2 \mu \mathrm{m}$ surface roughness value is considered the limit below which bacterial adherence is not expected [15].

In the present study, it was observed that the analysis of the surface roughness performed before and after the bleaching treatment in both groups (G1A, G2A, G1B and G2B - table 1 and 2) did not present a mean value above the critical value of $0,2 \mu \mathrm{m}$ presenting no significant statistical change. This can be explained by the fact that nanoparticulate resins (Z350XT - 3M ESPE ${ }^{\circledR}$ ), consisting 
of particles in the nanoscale of 0.4 to 0.8 nanometers, present a load increase around $80 \%$ due to the reduction in the size of the particles and the way of obtaining the load, providing a reduction of the polymerization and improvement in the mechanicalproperties of the resin [16]. This greater load amount of the material makes it less susceptible to bleaching agent's erosion [17]. Nonetheless, it was observed that after the bleaching treatment there was a slight increase in the mean surface roughness of the groups, although this increase was not significant. Therefore, it was shown that hydrogen peroxide acts through the release of free radicals and they can affect the resinous restoration leading to surface roughness increase [18].

Another aspect demonstrated in the obtained results is that the mean value of the roughness of the group submitted to the polishing treatment with the aluminum oxide discs after the bleaching treatment (G2A - table 1) was still less significant than the result obtained for the control group (G2B - table 1 and 2). Thus, it can be stated that the polishing treatment plays an important role on the surface roughness, as well as on the effect of the bleaching treatments on the composite resinslt is worth noting that, given the methodology used, these results can be considered as material-dependent once the preparation of the test specimens- through matrices- and the roughness obtained for the control group (GA - with polyester strip), although below the critical value, does not represent the daily clinic situation, since the restorations are performed with spatulas, brushes and textured with different instruments promoting different surface roughness values. It should be considered that the finishing and polishing procedures are also material-dependent results, since different resin types may respond differently to the same treatment, which can be explained by differences in size, shape, load and number of particles of each material [16].

Color stability is an increasingly important aesthetic issue regarding restorations [19]. Severalintrinsic or extrinsic factors may alter the color stability of composite resins. Among the intrinsic factors are the photopolymerizationtype and time as well as the material composition; extrinsic factors are the adsorption or absorption of pigments as a result of contamination by exogenous origin [20]. The composite resinstaining can be related to the type of resin and the load, which refers to the water absorption and hydrophilicity of the resin matrix 21 . Filtek Z350 XT resin $\left(3 \mathrm{M}^{\circledR}\right)$ presents an organic matrix consisting of BIS-GMA, UDMA, TEGDMA, PEGDMA and BIS-EMA, according to the manufacturer's data. Studies have shown that TEGDMA-containing resins present less color stability than TEGDMA-containing resins, therefore, TEGDMA may be responsible for resin staining [20].

In the results obtained by the present study, it can be demonstrated that the composite resin responds to home bleaching with statistical significance for color stability, that is, it presents darkening (table 3 and 4). The hydrophilicity of the organic matrix of the Filtek $\mathbf{Z 3 5 0}$ XT composite resin may be responsible for this, which promotes less color stability.

Published studies on color changes of composite resins after bleaching corroborate that bleaching agents can alter the color of restorations present on teeth, due to a superficial cleaning that the bleaching agent promotes on the surface of restorative material [21]. According to the literature and the study carried out, it is suggested that the composite resin restorations submitted to the bleaching be substituted if color alterations are perceived and aesthetics is impaired.

\section{CONCLUSION}

Within the limits of this study, it was concluded that the pre-contour strips containing $6 \%$ hydrogen peroxide do not cause a significant adverse effect on the roughness of the composite resin $Z 350 X \mathrm{XT}(3 \mathrm{M} 囚)$, however good polishing of the resins plays an important role in the reduction of the surface roughness prior to the bleaching treatments, in order to minimize problems caused by the increased roughness, such as biofilm accumulation and bacterial adhesion. However, it was also concluded that according to the color stability analysis performed, there may be an indication of the replacement of the restorations after the bleaching treatment, due to their color change.

\section{Collaborators}

IFAPM CALIXTO, MRD GAMA and LL FERRAREZ significant participation in study design, data collection, analysis/ interpretation of data and during the writing of the manuscript. JP CAMPOS, involvement in orientation of study, data collection, analysis/interpretation of data; and during the writing and revising of the manuscript. CW ABREU, involvement in study design, data collection and revising the manuscript. M OLIVEIRA, significant participation in the design of the study, statistical analysis and revision of the manuscript. 


\section{REFERENCES}

1. Ab-Ghani Z, Ooi QQ, Mohamad D. Effects of home bleaching on surface hardness and surface roughness of an experimental nanocomposite. J Conserv Dent. 2013; 16(4): 356-361. http:// dx.doi.org/10.4103/0972-0707.114362.

2. Pasquali EL, Bertazzo CA, Anziliero L. Estudo dos efeitos do clareamento dental sobre o esmalte: uma revisão das evidências para a indicação clínica. Perspectiva, Erechim. 2014; 38(141): 99-108.

3. Cardoso PEC, Pinheiro HB, Lopes BA. Perguntas e respostas sobre o clareamento dental. Rev Assoc Paul Cir Dent. 2014; 68(3): 236-237. Disponível em: < http://revodonto.bvsalud. org/pdf/apcd/v68n3/a10v68n3.pdf>.

4. Ramos $A B$, Monnerat $A F$, Perez $C R$. Avaliação da eficácia das fitas para clareamento dental. Rev. bras. odontol. 2014; 71(2): 198-202.

5. Demarco FF, Gluszevicz AC, Mendes MLM, do Nascimento MMC. Cabreira N. S. et al. Produtos de autocuidado para clareamento dental. RFO UPF. 2016; 21(1).

6. Fernandes HGK, Silva R, Marinho MAS, Oliveira POS, Ribeiro JCR, Moyses MR. Evolução das resinas compostas: revisão de literatura. Revista da universidade vale do rio verde. 2014; 12(2): 401-411. http://dx.doi.org/10.5892/ruvrd.v12i2.1465.

7. Aleixo RS, Bittencourt BF, Martins GC, Ficinski R, Gomes OMM, Farhat PA. Efeito do clareamento na susceptibilidade ao manchamento de uma resina composta. Odontol. Clín.Cient. 2013; 12(1): 59-63.

8. Lima RBW, Oliveira JA, de Vasconcelos LC, Andrade AKM, Duarte RM. Avaliação da rugosidade superficial e análise morfológica de cimentos de ionômero de vidro: influência do armazenamento em saliva artificial. Rev Odontol UNESP. 2017;46(2): 116-123. https://doi.org/10.1590/1807-2577.20 716

9. Salvego RN, Dias RPB, Figueiredo JLG. Estabilidade de cor de resinas compostas no processo de manchamento e clareamento. Rev Dental Press Estét. 2013;10(3):54-62. Disponível em <https://www.dentalpress.com.br/portal/ estabilidade-cor-resinas-compostas-processo-manchamentoclareamento/>

10. Gurgan S, Yalcin F. The effect of 2 different bleaching regimens on the surface roughness and hardness of toothcolored restorative materials. Quintessence Int. 2007; 38(2): 83-87. https://doi.org/10.1016/j.dental.2004.07.011

11. Silva VB, Ribeiro IC, Sena IAA, Vieira JIN, Seabra EJG, et al. Lisura superficial da resina composta frente a técnicas de polimento. Rev Bras Odontol. 2015;72(1-2): 47-50.
12. Ferreira $H$. de A, Carlo HL, e Silva FDCM, Meireles SS, Duarte RM, de Andrade AKM. Influência de agentes clareadores nas propriedades superficiais (rugosidade e microdureza) de uma cerâmica odontológica. Cerâmica. 2016;62(361):55-59. https://doi.org/10.1590/0366-69132016623611981

13. Bodanezi A, de Bittencourt ME, Bodanezi RV, Zottis T, Munhoz E, Carlini B. Surface modifications on aesthetically restored teeth following home bleaching with $16 \%$ peroxide carbamide. Eur J Dent. 2011; 5(2): 157-162.

14. Oliveira JR, Paradella TC, Rego MA, Koga-ito CY, Jorge AOC. Avaliação da aderência microbiana e rugosidade superficial de resina acrílica quimicamente ativada após clivagem com diferentes soluções desinfectantes. Ciênc Odontol Bras. 2007;10(2): 54-60.

15. Cruz J, Sousa T, Cavalheiro A, Pequeno A, Romão B, Coito C. Análise da rugosidade de superfície e da microdureza de 6 resinas compostas. Rev Port Estomatol Med Dent Cir Maxilofac. 2016; 57(1):38-45. https://doi.org/10.1016/j.rpemd. 2015.11.010

16. Tapia LR, Amaral FLB, França FMG, Flório FM, Rodrigues JA, Basting RT. Rugosidade de resinas compostas submetidas a diferentes métodos de acabamento e polimento. Rev Odontol UNESP. 2012;41(4):254-259.

17. Pozzobon RT, Candido MSM, Rodrigues Júnior AL. Análise da rugorosidade superficial de materiais restauradores estéticos. Efeito de agentes clareadores e tempo. Rev Odonto Ciência. 2005;20(49):204-209.

18. Wattanapayungkul P, Yap AUJ. Effects of in-office bleanching products on surface finish of tooth-colored restorations. Oper Dent. 2003;28(1):15-19.

19. Silva JC, Silva DR, Barbosa DN. Estabilidade de cor da resina composta: Um desafio para a dentística restauradora. Arch Health Invest. 2017;6(10):451-457. http://dx.doi.org/10.212 70/archi.v6i10.2240

20. Awliya WY, Al-Alwani DJ, Gashmer ES, Al-Mandil HB. The effects of commonly used type of coffee on surface hardness and color stability of resin-based composite restorations. Saudi Dent J. 2010; 22(1):177-181. http://dx.doi.org/10.1016/j. sdentj.2010.07.008

21. Farinelli MV, de Paulo PR, Nogueira RD, Geraldo-Martins VR. Efeitos do clareamento dental em restaurações de resina composta. UNOPAR Cient Ciênc Biol Saúde. 2013;15(2):153-159.

Received on: 17/11/2018 Final version resubmitted on: 28/6/2019 Approved on: 10/11/2019 